\title{
Disengagement in Art Education: Curriculum as Institutionalized Knowledge Marilyn L. Lapacinski
}

\author{
Background of Study
}

The subject of this study is the issue of student resistance to art curricula and teaching. There have been a number of significant studies related to the issue of student disengagement, especially among working-class youth. There have also been some interesting theories as to what perpetuates disengagement, what can prevent it and how it is manifested in the schools. From my own experiences as an art teacher, I have evidenced some weaknesses, not only in the structure of course content, but also in the structure of schooling itself. As a function of the hidden curriculum, students are often placed or tracked into art courses because of class, race and gender. In the case of class, the working-class student may be placed in or encouraged to take a "hands-on" course in order to develop the technical skills of following directions, using tools, performing manual labor versus mental labor, and developing efficient production techniques. The inequalities can be evidenced as rough representations of future divisions of labor, such as skilled/unskilled, whitecollar/bluecollar, "dumb"/"smart", or verbal/non-verbal. From other teaching experiences, I frequently noticed that working-class disengaged students "got stuck" in art courses without intending to enroll. In one situation, I recall a group of five "potential dropout" students who were placed in a pottery course I was teaching. The class was apparently selected for them by their counselor because they informed me that they did not choose to be there. These students acted out their resistance in a manner in which they performed enough to get by, but their main objectives were to socialize and "goof off." By resisting the formal art curriculum, they also developed a sense of solidarity with each other based upon the development of aggressiveness, sharpness of wit, humor and sarcasm. Another view as to the reason why this goofing off may have occurred, is that the students may not have taken the course very seriously. Because this high school curriculum was similar in many ways to a hegemonic curriculum which centers around "academic" knowledge, other kinds of knowledge were marginalized. The pottery class did not have the academic stamp of approval, distinguishing it from the dominant form of knowledge, therefore it was thought of as subordinate. The marginalizing was done not only by the school, but also by the students.

In another example of tracking, I often noticed that more working-class female students would be in the art courses which were in three-dimensional media, such as weaving, batik, pottery, jewelry and textiles. The hidden curriculum was being implemented in these art courses, as the

Working Papers in Art Education 1991 
girls were being channeled into courses which would prepare them for a career in the home; specifically those that taught tidiness, fashion, needlework and production skills which could be applied in the domestic realm. In the dominant, formal curriculum, girls are expected to be tidier than boys, thereby producing work which "looks pretty" more or less regardless of its content. Moreover, it is assumed that because girls are inherently neater, etc., they will also be successful in art courses. If a female student challenges her subordination and resists by deciding to pursue freedom of expression by being spontaneous with materials, thereby creating abstract, non-representational work outside of the established order, or more like the boys' work, she is seen as a failure. Consequently, through these classroom processes, inequities are made to seem normal and failure is made to appear as a personal problem. (Popkewitz, 1987)

I am particularly interested in looking at working-class youth, since it appears as if they have been targeted more often for hands-on courses, such as art, industrial arts and clerical training than for courses involving only mental activity. In fact, in some schools technical education is increasingly marginalized, and avoided by successful students. (Connell, Ashenden, Kessler, Dowsett 1982) In Working Class Without Work: High School Students in a De-industrializing Economy, (1990), Weis points out that public high schools in working-class communities serve to track students directly into blue-collar jobs. She quotes a passage from Rusted Dreams, by Ed Sadlowski who writes about how he and his friends were tracked into an industrial arts curriculum precisely because on the school questionnaire his answer to the question "What does your dad do?" was steelworker. "The counselor would put you into industrial arts. A fancy name for you know what. That's where me and my pals wound up making little holes in glass to make chimes." (Weis, 1990, p. 175) Clearly, this type of tracking is not meeting the needs of working-class youth who are being faced with different futures than their parents: a de-industrialized economy. Furthermore, what Weis found out through parental interviews, is that parents desperately want their children to attend college. Given de-industrialization, the parents in her study could not stress the importance of schooling more. (Weis, 1990) This data about what parents and families want for their children, parallels that of Connell, Ashenden, Kessler and Dowsett in Making the Difference (1982). In this well known study of Australian high schools, families, and social divisions, it is noted that working-class parents' support for their children's schooling is due to the notion that they believe more schooling equals better jobs, and a way of providing security for their children's futures.

Although there is evidence suggesting that parents want schooling and social mobility for their children, in some cases this may not be what students actually get or what they want. In Learning to Labor: How Working Class Kids Get Working Class Jobs (1977), Willis describes a working-class group of boys in an industrial city in England and their school relations. This study details some important theories and helps to clarify the notion of student resistance among high school boys. Primarily, he shows

Working Papers in Art Education 1991 
how 'the lads', through their own activity, reproduce themselves as working-class through their opposition to authority and their refusal to submit to the requirements of a curriculum that would encourage social mobility. In this study it shows the opposition between the informal structure of 'the lads' and the formal structure of the school. To 'the lads' the formal school structure which represents mental work, carries with it the threat of a demand for obedience and conformism. Resistance to mental work becomes resistance to authority as learned in school. Clearly, these working-class boys cast aside the dominant cultural sphere. In contrast, the other students who conform and accept the formal structure of the school, the 'ear'oles', are seen as having lost a sense of autonomy, but also as having gained an important exchange: knowledge for qualifications, thereby gaining social mobility for their future world of work. Hence, in the minds of 'the lads' there is a direct link between school and work, therefore they have adopted and developed to a fine degree their school counter-culture working-class attitudes such as resistance, subversion to authority, penetration of the weaknesses of the formal and an ability to create humor and diversion in school or the workplace. The 'ear'oles' /lads' division is seen as a very likely future division between skilled/unskilled or white collar/blue collar labor. Willis's study sharpened my thinking in relation to the difficulties inherent in reproduction theory. It seemed that a cultural approach would help create a point of view which could enable one to examine the schooling that appears to reproduce the existing social order, which is marked by disparities in wealth, power and privilege. An important view is that adolescents are not passive recipients of social movements or culture, whether dominant or otherwise. (Apple, 1982, Connell et. al, 1982, Everhart, 1983, Weis, 1990) According to Weis, the formation of working-class youth identity is related to the school and teacher culture as well as to larger social movements such as de-industrialization and the post-industrial society. (Weis, 1990) For example, jobs available in the United States are different from those even 10 years ago. The jobs which the white working-class depended upon have been severely eroded and white working-class youth are the victims or recipients of this post industrial society. Hence, the social identities of these youth are an interesting question as the formation of their identities will affect the struggles of the future. (Weis, 1990)

As part of their schooling, adolescents' identities may be encouraged or blocked by a variety of factors within the institutional culture. In Willis's study, there is the opposition between the formal or official ideology of the school and the informal which 'the lads' perpetuate and which is part of their culture. As part of the formal structure, there is the mental work which 'the lads' resist, and as a result excludes them from future social mobility. In the art curriculum, through discussion and observation of art works, working class adolescents can gain knowledge of themselves by identifying with the artist, by sharing conflicts and other aspects of the human experience. Art can encourage students to be freely expressive on their own terms, rather than in the dominant mode of academic, linear, rational conceptions. As has been detailed, working-class youth typically resist the formal structure of school. Therefore, this resistance could be redirected by engaging the alienated

Working Papers in Art Education 1991 
students in a form of art learning which encourages them to make their own meanings of art. Their socially-constructed meanings may happen to coincide with what the artist intended, or their meanings may be resistant to it. Willis's study warns that disengaged working-class students respond not so much to the style of individual teachers, and the content of education as to the structure of the school and the dominant teaching paradigm in the context of their overall cultural experience. This has significance for art education, as there have been current reforms over the past two decades which have focused more on changing content and teaching styles than on rethinking the dominant teaching paradigm or the formal school structure.

One of these current reforms which attempts to implement changes in the content and teaching styles of art education, is discipline-based art specified by the J. P. Getty Foundation in Beyond Creating (1985). By searching for a way to reform the arts in order to achieve a higher status in the schools, the Getty approach tries to characterize other curriculum areas which stress the basics, the fundamentals, thereby making students believe they are learning the essential, cognitive skills. (Beyond Creating, 1985) The discipline-based form of art education can be described as perpetuating characteristic high status knowledge such as literacy, an emphasis on the written as opposed to visual presentation, individualism, and avoidance of co-operativeness, abstractness of the knowledge and its structuring and compartmentalizing independently of the knowledge of the student. As in this discipline-based movement, the persistence of arts reformers to distance learning from real life situations, by holding the arts up as icons or as ideals, produces a subject area which has little relevance for a contemporary high school student and can produce disengagement.

\section{Design of the Study}

Through this study, I hope to determine how secondary art students make sense of the institutionalized knowledge in the art classroom, and how they either accept or reject it. I would like to investigate in-use curriculum rather than printed materials, prepared commercial materials and so forth. I would like to experience the curriculum as a student in the class would, in order to see what substance one could derive from the class. Consequently, what emerged was a pilot study situated in a high school located in a small midwestern town. I primarily focused my participant observations on two Art I classes, one Photography class and one Commercial Art class. Within these classes, I observed two different art teachers, although on a few occasions I also observed one of the other art teachers who teaches in the school parttime. I took verbatim notes, conducted student and teacher interviews, gathered information on the written materials which the teachers prepared for these classes, and looked at the student art work. Hence, by triangulation, I was able to pursue answers to questions raised but unanswered by the other ways of gathering information. Of primary importance to note, however, is that the research design arose not from any desire to be scientific, but to apply common sense to the obtaining of information. Hence, since much of

Working Papers in Art Education 1991 
the dimension of art is often expressed through attitudes and dispositions as well as through "factual" information, the research strategy had to include ways of discerning not only the perceptions of one observer of what was being conveyed, but also the intent of the teachers, and the perceptions the students held of what they were hearing.

Two sources which helped me understand the participant observation methodology are Ethnography: Principles in Practice (Hammersley and Atkinson, 1983), and Field Research (Schatzman and Strauss, 1973). Another study which was invaluable, was Cusick's Inside High School (1973). According to Cusick, the best method of gaining a reasonable understanding of a social situation is to study it from the viewpoint of the groups which create it. Hence, the most adequate method is the field method of participant observation. Some critics of this method argue that since the subjects are usually limited in number and selected by chance, the resulting data, although interesting, are not transferable to other situations. Cusick maintains that it only appears this way on a superficial level, as people are usually more alike than they are different, and a clear description of behavior in one situation, will in some ways be similar behavior for others given the same situation. In this case, I only selected one art department in one high school and only a small number of students were involved in the study. It is hoped that because of this school's similarity to other high schools, one can gain a better understanding of the secondary art student in general.

What I have observed in this setting is similar to my previous theories concerning student resistance to art curricula and teaching. I have evidenced some of the same weaknesses in the structure of course content, and the structure of the institution of schooling, as I had experienced during my years as a secondary art teacher. Moreover, through these participant observations and interviews, I discovered that the students acted out their resistance in a. manner in which they performed enough to get by, but the main objectives were to socialize, goof off and have fun. By resisting the formal art curriculum, they developed a sense of solidarity among each other on the one hand, but on the other, they alienated themselves from the teachers and the institution. Hence, as 'the lads' cast aside the dominant ideology of schooling in Willis's study, these students also resisted the formal structure of the school. By opposing the dominant, formal structure of school, the students further exclude themselves from future social mobility.

\section{Significance of the Study}

There is the growing rise of educational conservatism, that is, a back to basics movement with basics defined as they have been traditionally defined--reading, writing, science and mathematics. At the secondary level, there seems to be a strong component of discipline which is an answer to society's demands to keep the kids under control, and to force rigor into the curriculum. However, with these issues, come other consequences, students' disengagement with the academic curriculum, further vandalism or retaliation

Working Papers in Art Education 1991 
to the people who represent authority, and more students who are being tracked into the art courses as a last attempt to achieve enough credits for a high school diploma. This study is significant because it will reveal how the disengaged art student makes sense of the institutionalized curriculum. It will detail the many ways students learn about art through their own methods of learning, that is, through regenerative knowledge. Related to these ideas, is also the question which will be discussed concerning what happens to an art student when ideology is imposed from the top? From the studies previously outlined, the notion of a simple process of reproduction must be eliminated. Even though schools are acting as agents in the reproduction of an unequal society and there is a hidden curriculum which attempts to teach norms and values to students that are related to working in this unequal society, the notion of students passively accepting the imposed ideology should be rejected. Moreover, there is the production of a privileged class in the schools which further engenders them to accumulate power in the form of material and cultural capital, and deprives others of the ability to succeed. In addition to this inequality, empirical studies show that teachers are not neutral when evaluating student work, as they place great emphasis on language and style, which are dependent on cultural capital and one's cultivated family background. (Brubaker, 1985) It is hoped that through the in-depth study of one high school that similarities to other high schools will be evident and others will gain better understanding of disengaged secondary art students.

\section{References}

Apple, M. W. (1982). Education and power. Ark Paperbacks: Boston, London and Henley.

Atkinson, P. and Hammersley, M. (1983). Ethnography: Principles in practice. Routledge: London and New York.

Beyond creating: A place for art in America's schools (198). The J. P. Getty Trust: Los Angeles, CA.

Brubaker, R. (1985, Nov.). Rethinking classical theory: The sociological vision of Pierre Bourdieu. Theory \& Society, 14 (6), pp. 745-774.

Connell, R., Ashenden, D., Kessler, S. and Dowsett, G. (1982). Making the difference: Schools, families and social division. George Allen \& Unwin: Sydney, London, and Boston.

Cusick, P. (1973). Inside high school. Holt, Rinehart and Winston, Inc.: New York.

Everhart, R. B. (1983). Reading writing and resistance. Routledge \& Kegan Paul: Boston, London, Melbourne and Henley.

Working Papers in Art Education 1991 
Popkewitz, T. (1987). The formation of school subjects and the political context of schooling. In Popkewitz, T. (editor), The formation of the school subjects, The Falmer Press: New York, Philadelphia and London.

Schatzman L. and Strauss, A. (1973). Field research: Strategies for a natural sociology. Prentice-Hall, Inc.: Englewood Cliffs, New Jersey.

Weis, L. (1990). Working class without work: High school students in a de-industrializing economy. Routledge: New York, London.

Willis, P. (1977). Learning to labor: How working class kids get working class jobs. Columbia University Press: New York. 